Article

\title{
Territorial Cohesion of What and Why? The Challenge of Spatial Justice for EU's Cohesion Policy
}

\author{
Mikko Weckroth ${ }^{1, *}$ and Sami Moisio ${ }^{2}$ \\ ${ }^{1}$ Helsinki Institute of Sustainability Science, University of Helsinki, 00014 Helsinki, Finland; \\ E-Mail: mikko.weckroth@helsinki.fi \\ 2 Department of Geosciences and Geography, University of Helsinki, 00014 Helsinki, Finland; \\ E-Mail: sami.moisio@helsinki.fi \\ * Corresponding author
}

Submitted: 15 March 2020 | Accepted: 12 August 2020 | Published: 3 December 2020

\begin{abstract}
Over the past two decades, both academics and policy makers have discussed the meaning of territorial cohesion in the context of the European Union (EU). This debate on the meaning and content of territorial cohesion is becoming increasingly important in a Europe that is facing multiple crises. This article contributes to the literature on EU's territorial cohesion policies by tracing the ways in which territorial cohesion has been defined, framed and justified as an EU policy. We analyse public speeches made by the acting commissioners for Regional Policy and inquire into the Cohesion Reports from 2004 to 2017 produced by the European Commission. In particular, we interrogate both the meaning of the concept of territorial cohesion and the justifications for pursuing territorial cohesion. We conclude with some critical remarks on the relevance of economic production-based definitions and justifications for territorial cohesion policies. Accordingly, we argue that treating macroeconomic production as an indicator of territorial cohesion harmfully consolidates a narrow understanding of societal wellbeing and development and imposes on all regions a one-dimensional economic scale to indicate their level of development.
\end{abstract}

\section{Keywords}

cohesion policy; European Union; inclusion; regional policy; spatial justice; territorial cohesion

\section{Issue}

This article is part of the issue "Cohesion in the Local Context: Reconciling the Territorial, Economic and Social Dimensions," edited by Anja Jørgensen (Aalborg University, Denmark), Mia Arp Fallov (Aalborg University, Denmark), Rikke Skovgaard Nielsen (Aalborg University, Denmark), Hans Thor Andersen (Aalborg University, Denmark) and Maja de Neergaard (Aalborg University, Denmark).

(C) 2020 by the authors; licensee Cogitatio (Lisbon, Portugal). This article is licensed under a Creative Commons Attribution 4.0 International License (CC BY).

\section{Introduction}

Territorial cohesion is a peculiar, elusive and contested policy that has become part of the territorial construction or what authors have conceptualized as the "territory work" of the EU (see Moisio \& Luukkonen, 2017), especially since the late 1990s. Unsurprisingly, the concept has also attracted increasing attention in academic circles, particularly since the early 2000s (e.g., Bachtler \& Mendez, 2013; Camagni, 2005). As a policy term, territorial cohesion discloses the ways in which EU policies and academic research on those policies are eventually coconstituted: All EU policies are influenced by academic work. The EU cohesion policy has indeed been characterized by increasing interactions between the policy and academic spheres of debate, at least during the past ten years (see, e.g., Bachtler, Berkowitz, Hardy, \& Muravska, 2017). The recent EU Cohesion Policy reforms effectively disclose the ways in which scholars from the fields of regional studies, regional science and economic geography in particular have played important roles in shaping the new policy (McCann \& Varga, 2018). 
Territorial cohesion is closely related to fundamental and perennial questions in human geography, namely the reasons for and consequences of uneven geographical development (Hadjimichalis, 2011; Massey, 1984; Myrdal, 1957). Moreover, despite its origin in the political sphere of the EU, territorial cohesion has a thematically close connection to academic discourses on spatial justice and place-based development (see, e.g., McCann \& Varga, 2018). We further address this issue in the final section of this article with particular reference to the concept of spatial justice. Despite having its roots in the North American context and the urban realm the idea of spatial justice has been increasingly discussed with interregional framing over the last few years (see, e.g., Israel \& Frenkel, 2018; Jones et al., 2018; Rauhut, 2018).

Rather than examining how the discourses discussed in the analysis translate into specific policy instruments, such as structural funds, we present an analysis of the ways in which territorial cohesion is articulated and rationalized by key EU politicians as a meaningful policy. We therefore understand EU's "territorial cohesion" to be an ongoing policy process within which particular political rationalities, intellectual ideas and techniques of measuring are selected to form the nucleus of this policy at a given historical conjuncture. The elusiveness of territorial cohesion policy does not therefore mean that the selection of certain discursive elements of this policy would be totally haphazard; rather, the nucleus of a territorial cohesion policy always reflects the wider historically contingent systems of political-economic thought. Rather than understanding policy as a mere blueprint or outcome of political processes, we interrogate territorial cohesion policy as a discursive process whereby the content of policy is constantly re-worked among a range of actors operating with different capacities to act. Moreover, policy is a process that brings together different elements, such as ways of reasoning, systems of measuring, and techniques of governing. Even if there is an epistemic link between academic theories and the ways in which policy is rationalized, the focus of our analysis is not on the ways that territorial cohesion has been conceptualized in academic research. By contrast, we examine the ways in which territorial cohesion is defined and justified in EU policy-making. We underline that territorial cohesion has been a manifestation of political debates in the European social model, and the spatial development of the EU. In this sense, the evolution of territorial cohesion inescapably mirrors some of the broader developments in the process of European integration.

The agenda behind the use of territorial cohesion as a political term in EU policies appears to be to find justifications for the use of the Cohesion Fund and the European Regional Development Fund (ERDF) that aim to rebalance geographically uneven development within the EU. However, the question of whether the observed geographical differences in economic development are considered problematic in the first place, or whether these differences are merely spatial expressions of an efficient market economy, remains contested in academic literature (Martin, 2015). In the academic context this debate circulates around the fundamental question whether there is an efficiency-equity trade-off in regional economy (Martin, 2008). The ideas and arguments from these academic debates are then filtered through to policy making such as the EU's regional policy, which aims to strike a balance between different and sometimes conflicting arguments. This is exactly why we comprehend the EU's regional policy to be a trading zone of ideas and concepts between academics, planners and policymakers. In any case, the official stance of the EU Commission is that it aims to create an EU territory which is spatially balanced, and it is on this principle that the existence of EU funding is often justified. Consequently, the practice of introducing EU-originated spatial policy terms and wider policy discourses such as territorial cohesion can be seen as a strategy for producing and legitimizing the EU territory primarily as a form of governable spatial unit (Luukkonen \& Moisio, 2016).

The elusiveness and related political flexibility of territorial cohesion as a policy discourse in a wider set of EU policies is an important aspect: It can be re-formulated and acquire new meanings as current political-economic contexts change. From our perspective, an analysis of the evolution of a policy should also render visible the ways in which a particular political economy as well as academic concepts and theories are built into the policy discourse. This is important given that territorial cohesion is implemented by the channelling of public money across Europe. Hence, the way in which territorial cohesion functions as an investment mechanism is inescapably bound to the ways in which it has been reasoned and justified as an important policy for the further constitution of the EU as a polity. It is obvious that issues of economic growth, economic competitiveness and collective identity have figured prominently in the context of territorial cohesion policies over the past few years. Regrettably, the association and interconnections between cohesion policy and investment and/or redistribution has, however, been largely untouched in academic research so far. Given that territorial cohesion is a political and thus highly contested spatial policy-and under re-working within the EU apparatus-our analysis seeks to render visible some of the ways in which certain political economic reasonings receive a spatial character in the context of territorial cohesion policies over the past fifteen years or so.

\section{Analysing Territorial Cohesion Policy}

In academic research, territorial cohesion is often associated with regional differences without critically reflecting on its content and varying political meanings in policy practices. Many studies have used it in a descriptive manner-with pre-defined meanings for "territorial cohesion," territory and cohesion-to describe and compare certain economic and social conditions in 
and between EU regions. Beyond some notable exceptions (e.g., Davoudi, 2005; Faludi, 2004; van Well, 2012) the ideational and political content of territorial cohesion has not been systematically examined.

In the context of the EU, territorial cohesion is a policy discourse. It is historically contingent and its very meaning is constantly re-defined, re-worked and respatialized. Like all policy discourse, it is thus highly elusive. In EU policies, there is hence no single definition for territorial cohesion. On the contrary, the policy discourse of territorial cohesion has been articulated, measured and mapped through different spatial phenomena, such as disparities in economic production, forms of governance, and place-based policies (Camagni, 2005; Faludi, 2004; Medeiros, 2016; Mirwaldt, McMaster, \& Bachtler, 2008; Zaucha, 2015). These various spatial articulations of territorial cohesion are analysed in the latter sections of this article in order to disclose a sort of hierarchical structure of territorial cohesion as a policy discourse.

We approach the EU's territorial cohesion policy through scrutinizing public speeches made by the EU Commissioner of Regional Policy between 2005 and 2017 along with the 3rd to 7th Cohesion Reports. First, we examine how territorial cohesion is either implicitly or explicitly defined in the selected research materials. Second, we interrogate the moral, ethical, or economic justifications that are used for pursuing territorial cohesion. Third, we analyse whether any temporal shifts can be observed in the articulation of and justification for cohesion and territorial policies. These shifts are interesting not least given that the economic recession from 2008 onwards has had a significant impact on political developments within the EU.

The following questions structure our analysis:

1) How is territorial cohesion articulated (defined and framed) as a spatial policy in the research material?

2) What are the key spatial and political economic premises through which territorial cohesion is justified as a policy?

3) Have any changes occurred in the articulations (definitions and framings) of territorial cohesion during the period under investigation?

In other words, while interested in both the definition of and justification for territorial cohesion policy, our analysis addresses the questions of what and why. This way of interrogating territorial cohesion draws from one of the most distinguished authors on inequality and justice, Amartya Sen. In Inequality Re-examined, Sen (1992) notes that any analysis of inequality should first begin by asking which metrics or dimensions should be examined when discussing or defining inequality in a given society (what) and only second which moral justifications are used to pursue it (why). Hence, the questions of what and why are inevitably connected and cannot be evaluated separately. Despite a currently rather rich body of literature on the concept and practice of territorial cohesion as the guiding principle of the EU's spatial policies (Davoudi, 2005; Faludi, 2007; Medeiros, 2016; Mirwaldt et al., 2008), this question does not appear to have been adequately scrutinized. Instead, questions on what "territorial cohesion" is and why it is pursued have been examined in isolation.

Scrutinizing the articulations of European Commissioners for Regional Policy as a form of persuasive communication discloses the implicit meanings of territorial cohesion, which are not necessarily presented in the official policy documents of the EU. Public speeches on territorial cohesion policy include both the ethos and logos typical of any political speech and also the distinctive metaphors that can be used for predicative or ideological purposes in the context of the EU (Charteris-Black, 2014). In our perspective, political speech is a form of language that is prepared by a speaker for a specific audience for a particular event and in a particular geographical locale. Political speech can be understood as a deliberative form of communication aimed at justifying a specific policy. This instrumentalist reading of political communication highlights the fact that building a consensus around a policy requires establishing shared values within the audience. We argue that an analysis of the terms, expressions, and metaphors of "territorial cohesion" used by EU's Regional Commissioners in public speeches effectively disclose the ways in which territorial cohesion of the EU is legitimized, understood, and practised as a form of spatial-political intervention. From this angle, territorial cohesion as a guiding principle of EU territorial policies appears to be a useful target for an analysis of political argumentation and communication.

\section{Research Material}

The primary data used in our analysis are the speeches made by the European Commissioner responsible for regional policy. These speeches were downloaded from the Rapid database, which contains all the press releases of the Commission. The database is run by the Communication Department of the European Commission, and all the material is freely downloadable. Using Rapid's search engine, those speeches made by the Commissioner for Regional Policy which contained both the words "territorial" and "cohesion" were selected for analysis. This procedure resulted in a dataset of 69 speeches from the years 2004 to 2017.

This period included four different commissioners: Danuta Hübner (Poland, 2004-2009), Paweł Samecki (Poland, 2009-2010), Johannes Hahn (Austria, 2010-2014), and Corina Crețu (Romania, 2014-2019). This period fits well with the research focus of this analysis, as it covers the period of burgeoning academic interest towards territorial cohesion (Jones et al., 2018), as well as the period of economic recession from 2008 onwards. The studies' period also covers three program- 
ming periods: 2000 to 2006, 2007 to 2013, and the current period 2014 to 2020 .

The primary research material is supported by secondary data from the Cohesion Reports from the period spanning from 2004 to 2017. Cohesion Reports are produced by the European Commission every three years to report on progress towards achieving economic, social and territorial cohesion across the EU. The studied period covered five Cohesion Reports, from the third report (2004) to the seventh report, which was released in 2017.

These two above-mentioned datasets are taken to provide a comprehensive perspective of different articulations, definitions, and justifications of territorial cohesion. These articulations are politically important as they also implicitly legitimize the spatial channelling of Cohesion Funds and the ERDF, which have the strongest spatial or regional focus among the instruments in the European Structural and Investment Funds.

\section{The Territorial Cohesion of What? The Change in the Meaning of Territorial Cohesion}

The first result of our analysis concerning what territorial cohesion is is that the primary meaning attached to the policy concept of "territorial cohesion" during the programming periods 2000 to 2006 and 2007 to 2013 seems to refer to the level of regional disparities in economic production expressed through Gross Domestic Product (GDP). The dominance of this understanding is unsurprising, as the central aim of the EU set out in the Treaty is to promote economic and social progress and a high level of employment and to achieve a balanced and sustainable development.

Taken as a whole, the utilization of "territorial cohesion" as a component in achieving the EU goals of competitiveness and economic growth emphasizes the sheer political-economic dimension of cohesion. Moreover, throughout the programming periods 2000 to 2007 and 2008 to 2013, this dimension has been largely fixed on macro-scale economic production (instead of, for example, purchasing power or household income) and its most commonly used indicator - the GDP. In EU's territorial cohesion policy, the focus on regional disparities in macro-economic production emerges as the most common definition.

The strong emphasis on macroeconomic production during the first two programming periods under investigation is not a great surprise. At that time, cohesion policy was largely understood and articulated as contributing to the EU agenda of economic growth and competitiveness. This mirrors the findings of Mirwaldt et al. (2008) and Zaucha and Szlachta (2017), who noted that since the time of the third Cohesion Report in 2004, the term territorial cohesion was strongly connected with achieving the objectives of the Lisbon Agenda: competitiveness, innovation and employment. In territorial cohesion policy, the EU was understood as a "growth ma- chine," and the very rationale for territorial cohesion was framed as an agenda for narrowing regional disparities. Territorial cohesion was about increasing the performance of the regions in the new member states in particular and in so doing bringing these new members closer to the EU average. Consequently, this convergence would raise the cumulative economic output of the new EU territory as a whole. This understanding of territorial cohesion is articulated in the Third Cohesion Report (Commission of the European Communities [CEC], 2004), for instance:

If the EU is to realise its economic potential, then all regions wherever they are located, whether in existing Member States or in the new countries to join, need to be involved in the growth effort and all people living in the Union given the chance to contribute. (CEC, 2004)

This and other similar framings of territorial cohesion as an economizing spatial policy through which growth can be achieved received its definition through the broader EU agenda of the time. The justification of territorial cohesion stemmed from its potential contribution to both economic growth and the geopolitical construction of supranational territory.

At around the same time, however, an analysis of our research material discloses another meaning of territorial cohesion. An alternative meaning of territorial cohesion focuses more on an individual perspective rather than relying on indicators of macroeconomic production. This second meaning defines "territorial cohesion" as a spatial condition where "[p]eople should not be disadvantaged by wherever they happen to live or work in the Union' (CEC, 2004).

This individually focused place-based justification for territorial cohesion seems to have gained ground during the past few years. Interestingly, this justification has done so at the expense of the previously dominant focus on macroeconomic disparities between regions. In particular, this definition has its roots in the concept of the "accessibility of services of general economic interest," which was first introduced in Article 7d in the Amsterdam Treaty (CEC, 1997). The emphasis on accessibility adds a new political-economic component to territorial cohesion and reflects a qualitative shift from highlighting the economic performance of regions to underlining the structural strengths and weaknesses of regions. This more individually focused framing of territorial cohesion has been clearly visible during the last few years, particularly throughout the programming period from 2014 onwards. Even though the definition still maintains the emphasis on the instrumental economic and physical dimension it nonetheless switches the focus from macroeconomic indicators of production to the individual-level structural issues. This emphasis on the individual-level effects of changes in the macroeconomic context is evident when Commissioner Crețu reviewed 
the 7th Cohesion report in Brussels in October 2017. She noted that 'the [financial] crisis has left deep scars on Europe's socio-economic fabric....and in too many European Regions, people are poorer that they were before the crisis' (Crețu, 2017d).

The place-based focus stems originally from an emphasis on access to "services of general economic interest" (CEC, 1997) and in its current form it is based on a "universalist" argument that people should not be disadvantaged based on their place of residence in EU member states and regions.

The qualitative transformation of the discourse of territorial cohesion is also visible in the indices and indicators that have been used to render visible and articulate territorial cohesion within the EU policy apparatus. Even though for most of the period under investigation regional levels of macroeconomic production have been the dominant index through which "territorial cohesion" has been assessed, the latest programming period has seen an increasing number of remarks on the limitations of GDP as an indicator of development and wellbeing. More specifically, this acknowledgement of the limitations of GDP and calls for better indicators appear to have strengthened since 2010. For example, in 2010 Commissioner Hahn noted that there was 'an inherent need to develop more indicators for different thematic approaches. For territorial and social cohesion we could for example look at household income per head, access to health care or education' (Hahn, 2010).

The concern regarding GDP as an optimal indicator for measuring the results of Cohesion Policy was expressed again by Hahn in 2014, when he noted that 'another question we have to reflect upon is whether GDP should remain the main criterion for determining the needs and evaluation of the impact [of Cohesion Policy]' (Hahn, 2014).

The criticism towards the GDP-based understanding of territorial cohesion has gained even more ground during the time of Commissioner Crețu. In 2017 Crețu formulated this position with the remark that 'GDP, alone, does not accurately enough reflect the needs of a region as it leaves out crucial parameters such as quality of life, social inclusion or sustainable development' (Crețu, 2017b).

These remarks pointing to questions of quality of life and household income also highlight the more individually concerned approach to territorial cohesion. In this line of reasoning, territorial cohesion appears more concrete from the individual perspective than when associated with changes in macroeconomic production. However, it is clear that understanding territorial cohesion through an individual lens rather than focusing on changes in the macroeconomic context enables (and requires) the generation of new meanings for territorial cohesion. It is possible that this opens up ways towards a more nuanced understanding of the ways in which different places and regions have been left (and kept) behind (Rodríguez-Pose, 2018) through public and private investment policies and other political-economic issues that have to do with the post-Fordist economy and the associated new spatial division of labour.

\section{Why Territorial Cohesion? The Changing Justification for Territorial Cohesion as a Regional Policy}

One of the key justifications for territorial cohesion stems from aiming for an EU territory with small interregional differences in terms of economic production. However, the reasons for aiming at this goal can be articulated in different ways. More explicitly, striving for small regional disparities in GDP could essentially be justified on the grounds of either economic efficiency or spatial justice and solidarity. The different type of justifications for territorial cohesion can be teased out from the speeches of Commissioners of Regional Policy. This is the issue we now turn to.

Our research material demonstrates that arguments for practising territorial cohesion-when understood in terms of regional differences in GDP-are based on a rather peculiar mix of calls for economic efficiency (leading to the maximization of EU output throughout the entire EU area) and to idea of solidarity as a fundamental principle of the EU. When these arguments do not easily converge, the argument on economic efficiency usually prevails, whereas references to solidarity remain constantly vague. During the first programming periods (from 2000 to 2013), when the dominant definition of territorial cohesion concerned primarily macroeconomic production, the rationale of economic growth massively overshadowed ideas of solidarity or spatial justice. This is a notable issue: Territorial cohesion was for some time separated from important community and local level issues such as social inclusion, justice, participation, and the environment. During the first programming period, in particular, territorial cohesion acquired its meaning almost solely through economic growth, while one of the founding premises of European integration, solidarity, remained unspecified in the policy discourse of territorial cohesion.

Interestingly, the idea of solidarity was expressed in a speech by Commissioner Hübner at the Informal Ministerial Meeting on Territorial Cohesion and Regional Policy in 2007. She stated: 'I think we all agree that European cohesion is about solidarity and economic progress' (Hübner, 2007c).

This excerpt highlights the broader perennial struggle, both in territorial cohesion policy and within the EU as a whole, to strike a balance between the ideas of growth and redistribution of economic assets: the ongoing struggle between late Keynesian and Ordoliberal political economic reasoning. Moreover, the attempt to circumnavigate between ideas and practices of solidarity and efficiency was also evident in a speech by Commissioner Hübner in 2008. In this speech, she quoted the words of Jacques Delors, the former President of the European Commission, when describing the dynamics driving the European Union (EU) '[it is] 
competition that stimulates, co-operation that strengthens and solidary that unites' (Hübner, 2008).

The logic on the stimulating effect of competition is quite straightforward, but when referring to solidarity Hübner defined its complex connection to the EU's economic objectives as follows:

Last, but not least, [it is] solidarity that unites. Increasing globalisation and a shift towards knowledge based economy could widen the extent of social exclusion in Europe. This is not only a concern of social justice, the unemployed and the excluded are a resource wasted for society. The European Union cannot afford increasing social polarisation. (Hübner, 2008)

This attempt to integrate ideas of social inclusion and justice into the post-Fordist knowledge-based economy rationale is highly interesting. We already know that the process of knowledge-based economization has the capacity to abandon certain populations and to situate them outside political normativity. Indeed, the rise of neoliberal knowledge-based economization in Europe and beyond is clearly associated with the emergence of "places that do not matter" (Rodríguez-Pose, 2018) and "people who do not matter" (Moisio, 2018a). However, in Commissioner Hübner's (2008) line of reasoning, social exclusion, polarization, and unemployment need not be addressed primarily on their own but because they present an economic burden which the EU cannot afford. The similar economizing logic of attempting to incorporate solidarity into arguments of economic efficiency is clearly visible throughout our research material. For example, in a speech at the European Constitution and Solidarity Conference in 2005, Hübner, after stating that solidarity was a 'basic value of the union' and that 'the $10 \%$ of the population in the least developed regions contribute[d] only $2 \%$ of EU GDP', went on to claim that 'the Commission believes that all regions must participate in the growth process and that the cohesion policy should be available to all of them' (Hübner, 2005).

Furthermore, the pressing need for economic efficiency is reasoned on the premise that as the EU plays a relatively small role in the global economy, Europeans cannot afford to have regions that are "lagging" behind. Hübner, for instance, continues by noting that 'the EU has 254 regions, yet Europe is a small continent. We cannot afford to waste resources. We cannot afford to leave behind even the smallest region. All of them should contribute to raising European growth and competitiveness' (Hübner, 2005).

The assertion that all regions should contribute to economic growth is sometimes turned into claims that they have a responsibility to contribute to growth. In this line of reasoning, the idea of the territorial potential embedded in the poorer regions becomes understandable as a political-economic strategy. Thus, an important line of reasoning of territorial cohesion con- cerns perceiving regions as if they were characterized by underused or underutilized (economic) potential which could be harnessed for economic growth on an EU scale. Consequently, wording where territorial cohesion aims to unleash the territorial potential of regions has been present throughout the studied period. Hübner (2009), for example, asserts that 'poor regions are underutilized resources that could be contributing to overall EU growth' (Hübner, 2009).

This idea of underutilized potential being the reason for uneven economic distribution within the EU can be seen as an attempt to merge the notion of the spatial redistribution of resources with that of spatially focused investments. Throughout its existence, the territorial cohesion policy, and its manifestation in the channelling of strategic funds, has faced the question of whether it is conceived as a mechanism of redistribution or investment. Again, this brings us back to the tension between Ordoliberal and Keynesian fiscal and economic policies. Before the cohesion funds were explicitly defined as investment policy in the latest programming period of 2014 to 2020, the distinction between cohesion funds as social transfers (which have a spatial or regional nature) and investment method has been repeatedly articulated. The tension between the two ways of rationalizing cohesion funds is omnipresent in the speeches of commissioners during that period:

The structural funds are not designed as income transfers; they have the objective of funding real economic growth. (Hübner, 2004a)

Regional policy is not about hand-outs to underdeveloped areas. It is not a question of charity. Rather, it is about raising the long-term growth potential of regions, enabling them to attain a permanently higher level of development. It is about investing in regional competitiveness and jobs-in the endogenous growth potential of regions. (Hübner, 2004b)

In 2007, Hübner aimed to encourage collective selfreflection among the audience at the closing session of the Fourth Cohesion Forum by stating: 'We should ask ourselves why the [regional] policy is still perceived essentially as a simple redistributive instrument' (Hübner, 2007b).

However, in the same year, Hübner (2007a) had argued that a paradigm shift was occurring in the understanding of territorial cohesion:

New policy paradigm is emerging in the globalised economy where public policies are increasingly geared towards resource allocation rather than redistribution. It is a paradigm in which the "catchingup" on the part of the less developed with the advanced regions is dependent on jointly moving forward. It is a paradigm that stresses opportunities for the future, by mobilising underexploited potential, 
rather than compensating for the problems of the past. (Hübner, 2007a)

Nevertheless, this paradigm shift did not seem to have materialized four years later in 2011, when Commissioner Johannes Hahn articulated the persisting problems of understanding cohesion funds as an instrument of redistribution: ' $[1]$ think it is high time to move away from the traditional view of cohesion policy as a redistributive instrument, as a simple transfer of financial resources from rich to poor regions' (Hahn, 2011).

However, a few years after this remark, in the new programming period, cohesion policy was explicitly labelled as investment policy in EU documentation. This was acknowledged by Hahn in the closing speech of the 6th Cohesion Forum:

Cohesion Policy had to become a real strategic investment policy for the regions contributing to the achievements of EU goals. (Hahn, 2014)

The mind-set of people has been changed. Nobody thinks anymore of Cohesion Policy as a pot of money to be given to the regions. Nowadays people appreciate and understand the investment philosophy of the new Cohesion Policy. (Hahn, 2014)

The metaphor of a "pot of money" attaches a negative connotation to cohesion funds as the ineffective redistribution of public funds. In this case, the purpose of referring to cohesion policy as a "pot of money" was thus to imply negative evaluations of previous approaches to territorial cohesion policy. In sum, the rhetoric used in the Commissioners' speeches during the programming periods 2000 to 2007 and 2008 to 2013 highlight reasoning whereby redistribution and investment are mutually exclusive ways of organizing and developing political communities. This idea has, however, been highly controversial in terms of the founding principles of the Keynesian welfare statehood model in which redistribution is understood as an investment that generates economic growth. The expressions used in the Commissioners' speeches reveal a tension between ideas of redistribution and investment as well as rhetorical attempts to consolidate these two. We argue that this contradiction and tension is revealed through an analysis of speeches; the more descriptive and neutral cohesion reports do not articulate these dimensions of territorial cohesion policy.

The idea of public investment has been of increasing importance in the EU's articulation of justification for territorial cohesion over the past few years. As noted in the earlier section, the meaning of territorial cohesion has become more individually focused in recent years. Moreover, the more recent individually oriented definition of territorial cohesion territorial is increasingly grounded on the idea of solidarity. Based on the research material it appears that the concept of solidarity is now less associated with macroeconomic performance of re- gions than was the case during the first programming period. Commissioner Corina Crețu, for instance, argued in 2017 that '[c]ohesion policy brings European solidarity to each and every corner of the Union, ensuring everybody has access to the same opportunities, wherever she or he is' (Crețu, 2017a).

While reviewing the results of the Seventh Cohesion Report, Commissioner Crețu (2017d) further articulated spatially even opportunities by highlighting how:

More than ever, we must keep fighting disparities, making sure each and every European has access to the same opportunities, wherever she lives...and must keep promoting economic development, social inclusion, and equal opportunities in all EU regions. (Crețu, 2017d)

As these quotations show this new justification for territorial cohesion policies in the programming period from 2014 onwards is increasingly articulated with the notion of social inclusion. Thus, when attempting to establish a justification for territorial cohesion policies within the context of a more individually oriented definition, the Commissioner highlights investments in regional infrastructure, such as broadband connections or physical amenities, as acts of solidarity. Furthermore, it is also important to note that the new justification for territorial cohesions aims to overcome the redistribution/investments contradiction that is persistent in Ordoliberal political-economic reasoning. The justifications for territorial cohesion are now articulated with reference to the "visible" results it produces. In other words, the persistent Ordoliberal condition and the associated binary between investment policies and policies of redistribution does not play a significant role in the articulations of territorial cohesion from 2014 onwards.

The pragmatic rationale that regional policies create visible and positive results was expressed in a speech by Commissioner Crețu (2017b), who notes that '[cohesion policy] works because it fulfils the EU promise of providing access to basic services to all EU citizens, from drinkable water to broadband, from waste management to decent transport connections, from schools to kindergartens to hospitals' (Crețu, 2017b).

The amenity-oriented nature of Cohesion Policy was justified further in a speech by Crețu in the same year, where she remarked:

I often hear the example of the bicycle path in Bavaria or the swimming pool in Portugal to belittle what the policy does. Beside the fact that it is intellectually dishonest to reduce the policy to these examples, I would argue that if the bicycle path is part of a strategy to promote sustainable urban transport and the swimming pool part of an attempt to improve the quality of life in a deprived neighbourhood, the policy has fulfilled its mission. (Crețu, 2017c) 
In summary, it appears that during the latest programming period, the definition of territorial cohesion has become more based on the idea of physical infrastructures and the aim of social inclusion, and the articulations for its legitimacy have changed. During Crețu's tenure, the justification for territorial cohesion, and thus Cohesion Policy, has been built upon positive physical results for individuals, such as improvements in the quality of life and access to different services. However, it should be noted that deeper understandings of social inclusion or spatial justice are still largely absent in the framings of the territorial cohesion of the EU.

\section{Concluding Remarks}

Our analysis discloses that during the first two programming periods (2000 to 2013), the dominant meaning of territorial cohesion in EU's vocabulary referred to the difference in economic production (in terms of GDP) between the EU regions. During recent years, a shift occurred towards more individually focused definitions: access to services of general economic interest and spatially even distribution of opportunities. Referring to many regions in Europe as cases of underused territorial potential reflects the persistent attempts to label Cohesion and ERDF funding as investments rather than a channel of redistribution or "acts of charity." However, the justifications for territorial cohesion are still made on the basis of economic rationale. At the same time, issues of social inclusion are mentioned but narrowly defined in the framings of territorial cohesion.

Based on these findings we argue that a more contextual and individual-based approach to territorial cohesion, which is gaining more importance within EU terminology, could benefit from academic discourses on spatial justice, capabilities, and human agency. This approach to territorial cohesion would not only emphasize spatially equal access to services and opportunities, but also take into closer scrutiny other issues related also to the subjective quality of social and political life. Good infrastructure and access to services and amenities are important elements of territorial cohesion, and important dimensions to tackle uneven geographical development in the age of knowledge-intensive capitalism. But in order to increase the dimension of social inclusion through EU cohesion funds, notions regarding a broader range of opportunities, accessibilities, and capabilities to participate should be further specified and re-worked.

The recent literature on spatial inequalities and justice has shifted away from the spatial redistribution of goods and services and has begun to emphasize the role of recognition, participation and human agency (Israel \& Frenkel, 2018; Rauhut, 2018). For example, the conceptual framework by Israel and Frenkel (2018) for addressing spatial inequality is based on the socalled "capabilities approach" by Amartya Sen (1993), focusing on individual-level capabilities and opportunities. Interestingly, these theoretical notions converge with the two key findings of this analysis: a shift to a more individual-based definition of territorial cohesion and to an emphasis on more subjective measures of wellbeing and development. Even though the link between territorial cohesion policy discourses and the intellectual conceptualization of spatial justice remains loose, we see great potential in building linkages between the principles of individual-based territorial cohesion and academic literature on spatial justice, capabilities and agency. Additionally, there exists empirical evidence showing that measures of economic productivity and active human functioning and capabilities do actually converge in European regional context (e.g., Weckroth, Kemppainen, \& Sørensen, 2015). From policy perspective this would mean that shifting focus to more subjective dimensions of wellbeing and development in regions would not have to mean a degrowth in macroeconomic measures.

Territorial cohesion that would take its inspiration from spatial justice highlights that territorial cohesion is more than the maximization of economic efficiency or the visibility of EU-funded physical infrastructures. The principle of solidarity and social inclusion as guiding principles of cohesion policy could enjoy greater success and legitimacy than previous efforts to merge the idea of solidarity with the notion of lagging regions. In short, the idea of European solidarity should also take its motivation from empowering communities, protecting environments and fostering policies that are inclusive rather than exclusive at the level of regions, cities and communities. In this respect, EU policymakers could pay more attention to the ways in which spatial justice has been debated in academic literature.

Spatial justice is a concept which has its roots in theoretical discussions regarding how ideas of social justice and geographical space should be linked together (for an early account, see Harvey, 1973). If space is conceptualized as more than just a container for different kinds of social processes, then 'there is a need to reflect on the impact that defining spatial justice as a regional, as opposed to an urban, goal has on its meaning and operation' (Jones, Goodwin-Hawkins, \& Woods, 2020, p. 2). Indeed, despite having its roots in the North American context and the urban realm, the idea of spatial justice has been increasingly discussed with inter-regional framing during the last few years (see, e.g., Israel \& Frenkel, 2018; Jones et al., 2018; Rauhut, 2018).

A number of issues and processes can be associated within the notion of spatial justice while reworking EU's future regional policies. First, a diverse set of issues can be understood as key constituents of spatial justice, ranging from the equitable distribution of resources, functioning local and regional mechanisms for participation, individual and collective capacities to act, the existence of a safe and clean environment, and access to various services. In the context of territorial cohesion policy, these issues should not, therefore, be considered technical issues but instead basic human rights (cf. Soja, 
2010) and key constituents of spatial justice. Second, spatial injustice, in turn, refers to the political processes of marginalization, oppression, exclusion, exploitation and discrimination. Third, and related to the previous issues, spatial justice refers to the just and/or equal distribution of capital and other resources, functioning infrastructures, good governance, the lack of spatial burdens in society, and access to services and opportunities, to mention but a few structural themes (Barnett, 2011; Dikec, 2001). Fourth, spatial injustice refers not only to the unequal distribution of resources and services but also to an inequality of opportunities; ones that constitute the antithesis of geographies of justice. Finally, it is important to note that the experiencing of spatial injustice discloses structural conditions that limit an individual's or a region's capabilities and liberties 'to be and to do' (cf. Israel \& Frenkel, 2018, p. 648). Territorial policies that are predicated on spatial justice should, therefore, take into account the potentially marginalizing political, cultural and economic processes that reproduce spatial injustices in terms of both objective and subjective wellbeing, and in terms of experienced, lived and narrated injustices.

To conclude, the results of our analysis suggest that while the economic and political context within the EU has changed-not least because of the Covid-19 pandemic - a parallel change is also required at the level of policy language and broader discourse. When developing the theoretical and conceptual content for territorial cohesion in the new programming period from 2020 onwards, EU policymakers should give greater recognition to ideas of spatial justice. This approach could spatialize territorial cohesion in new ways that would have the potential to contribute more directly to the wellbeing of people in various parts of Europe (see also Jones et al., 2018). Moreover, this approach could contribute to the reworking of the so called place-based approach to regional development. A narrow reading of the placebased approach to EU's regional development considers it a mere neoliberal governmental technology of minimal political intervention that leaves most of the European regions and places to survive on their own under the imperatives of economic competitiveness and smart specialization. In such a "leaving behind" reading of the place-based development, the transformation of EU's cohesion policy towards "the individualization of regions" (Ahlqvist, \& Moisio, 2014) indicates a deepening neoliberalisation of the EU in the age of "strategic urbanization" of political communities and associated discourses of economic agglomeration (Moisio, 2018b). Another reading, however, highlights the fundamental elusiveness of the discourse of place-based development. In this second reading, the place-based development can be redirected towards developing policies that are predicated upon spatial justice and not only in the form of service accessibility or redistribution of funds to places and regions under peripherisation. Merging the discursive elements of place-based development, territorial cohesion and spatial justice can also entail a process whereby differ- ent kinds of regional actors are enabled and empowered to assert their various capacities to act and pursue positive visions of regional futures (Jones, Goodwin-Hawkins, \& Woods, 2020). This kind of approach to tackle uneven geographical development highlights the place and context specificity of the "good life" which inescapably reflects and is bound to particular regional and local priorities. In this latter respect, the cohesion policy of the EU has remained spatially blind.

As a final note we see that the understanding and evolution of the concept of wellbeing within EU (including regional) policies and documents would be an important area of future research. For example, further research is needed to analyse to what extent the shift in definition and measurement of territorial cohesion over the time period studied in this analysis is connected to a broader discussion on transition from income/GDP to more comprehensive measures of progress and wellbeing (e.g., Stiglitz, Sen, \& Fitoussi, 2009).

\section{Acknowledgments}

Our research for this article was enabled by the IMAJINE project, funded by the European Union's Horizon 2020 research and innovation program under grant agreement 726950 .

\section{Conflict of Interests}

The authors declare no conflict of interests.

\section{References}

Ahlqvist, T., \& Moisio, S. (2014). Neoliberalization in a Nordic state: From cartel polity towards a corporate polity in Finland. New Political Economy, 19(1), 21-55.

Bachtler, J., \& Mendez, C. (2013). EU cohesion policy 2007-2013: Are the goals of the 2006 reform being achieved? European Structural and Investment Funds Journal, 1, 15-19.

Bachtler, J., Berkowitz, P., Hardy, S., \& Muravska, T. (2017). (Eds.). EU cohesion policy: Reassessing performance and direction. Abingdon: Routledge.

Barnett, C. (2011). Geography and ethics: Justice unbound. Progress in Human Geography, 35(2), 246-255.

Camagni, R. (2005). The rationale for territorial cohesion: Issues and possible policy strategies. In P. Boscaino (Ed.), Present and future of the European spatial development perspective (pp. 121-138). Florence: Ministero delle Infrastutture e dei Transporti.

Commission of the European Communities. (2004). A new partnership for cohesion: Convergence, competitiveness and cooperation. Third report on economic and social cohesion. Luxembourg: Office for Official Publications of the European Communities.

Commission of the European Communities. (1997). 
Treaty on European Union-Treaty of Amsterdam. Luxembourg: Office for Official Publications of the European Communities.

Charteris-Black, J. (2014). Analysing political speeches: Rhetoric, discourse and metaphor. Basingstoke: Palgrave Macmillan.

Crețu, C. (2017a). Keynote speech by Commissioner Creţu at the Committees on EU Affairs and Regions of the Greek Parliament [Press Release]. Retrieved from https://ec.europa.eu/commission/presscorner/ home/en

Crețu, C. (2017b). Introduction and closing remarks by Commissioner Creţu at the Plenary Session [Press Release]. Retrieved from https://ec.europa.eu/ commission/presscorner/home/en

Creț, C. (2017c). Speech by Commissioner Cretu at the meeting of the COTER Commission of the Committee of Regions [Press Release]. Retrieved from https:// ec.europa.eu/commission/presscorner/home/en

Crețu, C. (2017d). Introductory remarks by Commissioner Creţu at the 7th Cohesion Forum [Press Release]. Retrieved from https://ec.europa.eu/commission/ presscorner/home/en

Davoudi, S. (2005). Understanding territorial cohesion. Planning Practice and Research, 20(4), 433-441.

Dikec, M. (2001). Justice and the spatial imagination. Environment and Planning A, 33(10), 1785-1805.

Faludi, A. (2004). Territorial cohesion: Old (French) wine in new bottles? Urban Studies, 41(7), 1349-1365.

Faludi, A. (2007). The European model of society. In A. Faludi (Ed.), Territorial cohesion and the European model of society (pp. 1-22). Cambridge: Lincoln Institute of Land Policy.

Hadjimichalis, C. (2011). Uneven geographical development and socio-spatial justice and solidarity: European regions after the 2009 financial crisis. European Urban and Regional Studies, 18(3), 254-274.

Hahn, J. (2010). Evaluation of ERDF objectives, 20002006 [Press Release]. Retrieved from https://ec. europa.eu/commission/presscorner/home/en

Hahn, J. (2011). Improving the impact of cohesion policy through an integrated place-based approach [Press Release]. Retrieved from https://ec.europa. eu/commission/presscorner/home/en

Hahn, J. (2014). Cohesion policy's contribution to common European goals [Press Release]. Retrieved from https://ec.europa.eu/commission/presscorner/ home/en

Harvey, D. (1973). Social justice and the city. London: Edward Arnold.

Hübner, D. (2004a). Lisbon and cohesion policy: Complementary objectives [Press Release]. Retrieved from https://ec.europa.eu/commission/presscorner/ home/en

Hübner, D. (2004b). Regional policy in the enlarged EU: How much reform do we need? [Press Release]. Retrieved from https://ec.europa.eu/commission/ presscorner/home/en
Hübner, D. (2005). Solidarity in the European constitution. [Press Release]. Retrieved from https://ec.europa. eu/commission/presscorner/home/en

Hübner, D. (2007a). Cohesion policy: A key lever for growth and jobs throughout the European Union [Press Release]. Retrieved from https://ec.europa. eu/commission/presscorner/home/en

Hübner, D. (2007b). Cohesion policy: Genuinely modern and still reinventing itself [Press Release]. Retrieved from https://ec.europa.eu/commission/ presscorner/home/en

Hübner, D. (2007c). Future of cohesion policy: Towards exploring options [Press Release]. Retrieved from https://ec.europa.eu/commission/presscorner/ home/en

Hübner, D. (2008). Future challenges and Europe's role as a leader to respond them [Press Release]. Retrieved from https://ec.europa.eu/commission/ presscorner/home/en

Hübner, D. (2009). Reflections on future cohesion policy [Press Release]. Retrieved from https://ec.europa. eu/commission/presscorner/home/en

Israel, E., \& Frenkel, A. (2018). Social justice and spatial inequality: Toward a conceptual framework. Progress in Human Geography, 42(5), 647-665.

Jones, R., Goodwin-Hawkins, B., \& Woods, M. (2020). From territorial cohesion to regional spatial justice: The well-being of future generations Act in Wales. International Journal of Urban and Regional Research. Advance online publication. https://doi.org/ 10.1111/1468-2427.12909

Jones, R., Moisio, S., Weckroth, M., Woods, M., Luukkonen, J., \& Meyer, F. (2018). Re-conceptualizing territorial cohesion through the prism of spatial justice: Critical perspectives on academic and policy discourses. In T. Lang \& F. Görmar (Eds.), Local and regional development in times of polarization: Rethinking spatial policies in Europe (pp. 97-120). Cheltenham: Palgrave Macmillan.

Luukkonen, J., \& S. Moisio (2016). On the socio-technical practices of the European Union territory. Environment and Planning A, 48(8), 1452-1472.

Martin, R. (2008). National growth versus spatial equality? A cautionary note on the new 'trade-off' thinking in regional policy discourse. Regional Science, Policy and Practice, 1(1), 3-13.

Martin, R. (2015). Rebalancing the spatial economy: The challenge for regional theory. Territory, Politics, Governance, 3(3), 235-272,

Massey, D. (1984). Spatial divisions of labour: Social structures and the geography of production. London: Macmillan.

McCann, P., \& Varga, A. (2018). (Eds.). Place-based economic development and the new EU cohesion policy. Abingdon: Routledge.

Medeiros, E. (2016). Territorial cohesion: An EU concept. European Journal of Spatial Development, 60, 1-30.

Mirwaldt, K., McMaster, I., \& Bachtler, J. (2008). Recon- 
sidering cohesion policy: The contested debate on territorial cohesion (European Policy Research Paper 08/05). Glasgow: University of Strathclyde.

Moisio, S. (2018a). Geopolitics of the knowledge-based economy. London: Routledge.

Moisio, S. (2018b). Urbanizing the nation-state: Notes on the geopolitical growth of cities and city-regions. Urban Geography, 39(9), 1421-1425.

Moisio, S., \& J., Luukkonen (2017). Notes on spatial transformation in post-Cold War Europe and the territory work of the European Union. In P. Vihalemm, A. Masso, \& S. Operman (Eds.), The Routledge international handbook of European social transformations (pp. 224-238). London: Routledge.

Myrdal, G. (1957). Rich lands and poor: The road to world prosperity. New York, NY: Harper \& Row.

Rauhut, D. (2018). A Rawls-Sen approach to spatial injustice. Social Science Spectrum, 4(3), 109-122.

Rodríguez-Pose, A. (2018). The revenge of the places that don't matter (and what to do about it). Cambridge Journal of Regions, Economy and Society, 11(1), 189-209.

Sen, A. (1992). Inequality re-examined. Oxford and New York, NY: Oxford University Press.

Sen, A. (1993). Capability and wellbeing. In A. Sen \& M.
Nussbaum (Eds.), The quality of life (pp. 30-53). Oxford: Clarendon Press.

Soja, E. (2010). Seeking spatial justice. Minneapolis, MN: University of Minnesota Press.

Stiglitz, J. E., Sen, A., \& Fitoussi, J. (2009). Mismeasuring our lives: Why GDP doesn't add up. New York, NY: New Press.

van Well, L. (2012). Conceptualizing the logics of territorial cohesion. European Planning Studies, 20(9), 1549-1567.

Weckroth, M., Kemppainen, T., \& Sørensen, J. (2015). Predicting the gross domestic product (GDP) of 289 NUTS regions in Europe with subjective indicators for human and social capital. Regional Studies, Regional Science, 2(1), 312-331.

Zaucha, J. (2015). Key dimensions of territorial cohesion: A review of the existing sources of information on territorial cohesion (Working Paper 008/2015). Sopot: Institute for Development.

Zaucha, J., \& Szlachta, J. (2017). Territorial cohesion: Origin, content, and operationalization. In J. Bradley \& J. Zaucha (Eds.), Territorial cohesion: A missing link between economic growth and welfare. Lessons from the Baltic Tiger (pp. 23-44). Gdansk: Department of Macroeconomics, Gdańsk University.

\section{About the Authors}

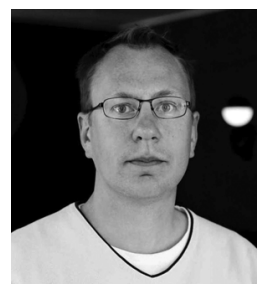

Mikko Weckroth is a Postdoctoral Researcher in the Helsinki Institute of Sustainability Science (HELSUS) at the University of Helsinki, Finland. His research has focused on empirical analyses on geographies of subjective wellbeing, human values, and urbanization as well as their interconnections. Additionally, he is interested on how the abovementioned concepts are articulated, rationalized and implemented in regional policies such as EU's cohesion policy.

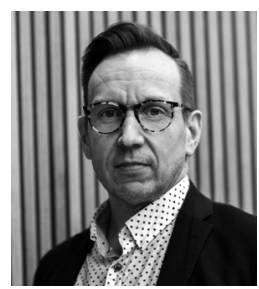

Sami Moisio is Professor of Spatial Planning and Policy in the Department of Geosciences and Geography at the University of Helsinki, Finland. His research interests include state spatial transformation, political geography of economic geographies, and urban political geography. His recent book, Geopolitics of the Knowledge-Based Economy, won the Regional Studies Association Routledge Best Book Award 2019. 